\title{
GOUT AND NONALCOHOLIC FATTY LIVER DISEASE: EFFECT OF ENTEROSORPTION'S ADDITION TO COMMON TREATMENT
}

\author{
U.O. Mudra \\ I. HORBACHEVSKY TERNOPIL NATIONAL MEDICAL UNIVERSITY, TERNOPIL, UKRAINE
}

Background. Gout is still one of the major health problems despite significant advances in treatment in recent years. It has been proved that pathogenetic mechanisms of development and progression of gout are associated with nonalcoholic fatty liver disease. Complex pathogenic treatment of patients aimed at different parts of the pathological process has recently been supplemented with the enterosorbents.

Objective. The aim of the research is to study the clinical features of gout with concomitant nonalcoholic fatty liver disease (NAFLD) and to evaluate the effect of carbon enterosorbent on its course.

Methods. 123 patients were involved in the study. They were divided into 2 groups: group 1 included patients with gout without liver damage, and group 2 included patients with concomitant NAFLD. Each of these groups was divided into subgroups, in which the patients received carbon enterosorbent carboline plus basic treatment. The control group consisted of 30 healthy persons. Anamnesis, physical examination, uric acid (UA), C-reactive protein (CRP) content, erythrocyte sedimentation rate (ESR) in serum were determined. Gout activity was evaluated using the Gout Activity Score (GAS).

Results. Basic treatment in combination with carbon enterosorbent contributed to faster cure of intoxication, pain and joint syndromes, as well as decrease of the inflammatory process activity.

Conclusions. The course of gout in the patients with concomitant NAFLD is more severe. Adding of carbon granular enterosorbent carboline in the complex treatment of patients with gout with or without concomitant NAFLD in the exacerbation phase contributes to a faster cureing dynamics of clinical and laboratory manifestations of the disease.

KEY WORDS: gout; nonalcoholic fatty liver disease; enterosorbent; treatment.

\section{Introduction}

Pathology of the articular apparatus is one of the most frequent and common human diseases. Salt arthropathy accounts for a large share, among which gout is the most common. Gout is a chronic progressive disease associated with impaired uric acid metabolism, which is clinically manifested by recurrent arthritis, tophi formation and internal organs damage [1].

Gout is certainly an urgent health issue and a significant social and economic burden for the country. According to the Ministry of Health of Ukraine, the number of gout patients in Ukraine has increased in recent years. Thus, in 2013, the prevalence of this disease was 167.6 per 100 thousand population, whereas in 2017 this figure reached 190.4 per 100 thousand population, and 113.9 - among the able-bodied population. The cost of treating new cases of

*Corresponding author: Mudra Uliana, Department of Internal Medicine Propedeutics and Phthisiology, 1 Maidan Voli, I. Horbachevsky Ternopil National Medical University, Ternopil, Ukraine, 46001.

E-mail: heliosmuo@gmail.com acute gouty arthritis in the United States is estimated at \$ 27.4 million annually [2, 3].

Pain and swelling of the joints during exacerbations of gout can lead to a significant deterioration and disability, which affects the patient's productivity and social activity. According to Edwards N.L. et al., a patient with gout, who is under 65 years of age, has an average of 25.1 working days a year due to the illness [4].

Uncontrolled administration of medicines for comorbid diseases, as well as malnutrition, alcohol abuse, hypodynamia, physical or psycho-emotional overload play an important role in increasing the incidence [5].

In recent years, researchers have paid particular attention to the multifaceted clinical manifestations of gout, which is not limited to damage of the musculoskeletal system and kidneys. A great number of patients suffer from obesity, disorders of lipid and carbohydrate metabolism, hypertension, which are integral parts of the metabolic syndrome $[6,7]$. 
According to the literature, metabolic syndrome is often aggravated by fatty liver infiltration, which can significantly affect the course of the underlying disease. Nonalcoholic fatty liver disease is the most common liver disease in the world ( $46 \%$ of the population, and $74 \%$ among diabetes patients) $[8,9]$.

Thus, the increase of gout incidence and development of concomitant pathology, which complicates its course, leads to a decrease in the effectiveness of treatment, development of complications and mortality, is an urgent issue at present that requires improved diagnosis and treatment.

Treatment of the patients with gout should be comprehensive, and include non-pharmacological and pharmacological methods. Physicians should take into account the level of uric acid (with subsequent monitoring), the form and stage of gout, radiological stage and degree of functional failure of the joints, patient's age, concomitant pathology and features of its pharmacotherapy. A key aspect of the treatment is strict diet, weight loss in obesity [10].

One of the current treatments is enterosorption, which is increasingly used in the treatment of acute and chronic diseases.

The objective of the study is to investigate clinical features of gout with concomitant nonalcoholic fatty liver disease (NAFLD) and to evaluate the effect of carbon enterosorbent on its course.

\section{Methods}

The study involved 123 patients with gout during the exacerbation period, including 118 (95.9\%) men and 5 (4.1\%) women. The average age was (57.73 \pm 1.01$)$. The diagnosis of gout was based on ACR/EULAR 2015 criteria and the order of the Ministry of Health of Ukraine No. 676 , dated October 12, 2006. The diagnosis of NAFLD was established according to the criteria of the Unified Clinical Protocol of Primary, Secondary (specialized) Medical Care "Nonalcoholic fatty liver disease" (Order of the Ministry of Health of Ukraine No. 826, dated November 6, 2014).

The history of the disease (duration of the disease, frequency of attacks for the last 12 months) was taken into account in clinical examination of the patients. They also underwent physical examination (determination of pain intensity by a visual analogue scale (VAS), evaluation of the number of tophi, affected joints, uric acid content (UA), C-reactive protein
(CRP), erythrocyte sedimentation rate (ESR) in the blood serum.

To assess the effectiveness of therapy, the patients of both groups were monitored for complaints (pain and swelling of joints, restriction of movement in them, etc.), evaluated for joint syndrome development, dynamics of the level of UA, CRP and ESR.

Gout activity was assessed using the Gout Activity Score (GAS) suggested by Sciere C.A. et al.:

GAS $=0.09 \times$ the number of attacks for the last 12 months $+1.01 \times \sqrt{ } \mathrm{UA}+0.34 \times$ patient's VAS $+0.53 \times \ln (1+$ number of tophi);

where UA - uric acid (mg/dl), VAS - visual analogue pain scale $(\mathrm{cm})[2,11]$.

All the patients were divided into two groups. Group 1 included 65 patients with gout without liver damage, group $2-58$ patients with concomitant NAFLD. The control group consisted of 30 healthy individuals of the same age.

All the patients voluntarily agreed to participate in the study. The Patient Safety Rules and the Ethical Standards and Procedures for Research Involving Human Beings (2000) were followed during the whole study.

Statistical processing of the results was performed using Statistica 10.0 software package (StatSoft, USA) and Microsoft Office Excel 2016 statistical software package (Microsoft Corp., USA). The statistical significance of differences between the groups was evaluated using the nonparametric Wilcoxon $U$ (MannWhitney) method. The differences were considered statistically significant at $p<0.05$.

\section{Results}

According to the medical history, the average duration of gout in all examined patients was $(8.75 \pm 0.50)$ years. Clinical and laboratory characteristics of patients with gout are presented in Table. 1.

Tophi were detected in 80 (69 \%) persons, in group 1 - in 36 (45 \%) patients, in group $2-44$ (55\%). It is worth noting that patients with NAFLD were predominant with multiple tophi.

When assessing the frequency of exacerbations of gout per year, a statistically significant increase in 1.5 times among the patients with concomitant NAFLD, compare to those without liver damage $(p<0.05)$ should be emphasized.

The analysis of the joints involved in the pathological process in the patients with gout without liver damage proved the following joints $(3.75 \pm 0.30)$ disorders: monoarthritis was detected in $24.6 \%$, oligoarthritis - in $29.2 \%$, 
Table 1. Clinical and laboratory characteristics of the patients with gout

\begin{tabular}{|c|c|c|c|}
\hline Parameter & Units & $\begin{array}{c}\text { Group } 1 \text { (patients } \\
\text { without NAFLD) } \\
(n=65)\end{array}$ & $\begin{array}{l}\text { Group } 2 \text { (patients } \\
\text { with NAFLD) } \\
(\mathrm{n}=58)\end{array}$ \\
\hline Age, years & $\mathrm{M} \pm \mathrm{m}$ & $59.55 \pm 1.33$ & $55.68 \pm 1.5$ \\
\hline Number of patients with tophi & $\mathrm{n}(\%)$ & $36(45)$ & $44(55)$ \\
\hline $\begin{array}{l}\text { Number of tophi: } \\
1-3 \\
4-9 \\
10 \text { and more }\end{array}$ & $\mathrm{n}(\%)$ & $\begin{array}{l}7(19.4) \\
19(52.8) \\
10(27.8) \\
\end{array}$ & $\begin{array}{l}14(31.8) \\
16(36.4) \\
14(31.8) \\
\end{array}$ \\
\hline Number of attacks for the last 12 months: & $\mathrm{M} \pm \mathrm{m}$ & $3.03 \pm 0.23$ & $4.67 \pm 0.19 *$ \\
\hline $\begin{array}{l}0 \\
1-2 \\
3-5 \\
6-10 \\
\text { More than } 10\end{array}$ & $\mathrm{n}(\%)$ & $\begin{array}{c}8(12.3) \\
14(21.5) \\
38(58.5) \\
5(7.7) \\
-\end{array}$ & $\begin{array}{c}- \\
4(6.9) \\
41(70.7) \\
13(22.4) \\
- \\
\end{array}$ \\
\hline Number of affected joints: & $\mathrm{M} \pm \mathrm{m}$ & $3.75 \pm 0.30$ & $5.36 \pm 0.38 *$ \\
\hline $\begin{array}{l}\text { Monoarthritis } \\
\text { oligoarthritis ( } 2-3 \text { joints) } \\
\text { polyarthritis } 4 \text { and more joints }\end{array}$ & $\mathrm{n}(\%)$ & $\begin{array}{l}16(24.6) \\
19(29.2) \\
30(46.2) \\
\end{array}$ & $\begin{array}{c}2(3.5) \\
17(29.3) \\
39(67.2) \\
\end{array}$ \\
\hline $\begin{array}{l}\text { Course: } \\
\text { mild } \\
\text { medium severity } \\
\text { severe }\end{array}$ & $\mathrm{n}(\%)$ & $\begin{array}{l}17(26) \\
41(63) \\
7(11) \\
\end{array}$ & $\begin{array}{l}7(12) \\
33(57) \\
18(31) \\
\end{array}$ \\
\hline Visual analogue scale (VAS), mm & $\mathrm{M} \pm \mathrm{m}$ & $56.34 \pm 1.00$ & $69.21 \pm 1.04^{*}$ \\
\hline Gout activity score (GAS) & $\mathrm{M} \pm \mathrm{m}$ & $7.53 \pm 0.28$ & $9.63 \pm 0.35 *$ \\
\hline Uric acid, $\mu \mathrm{moL} / \mathrm{L}$ & $\mathrm{M} \pm \mathrm{m}$ & $459.72 \pm 11.44$ & $621.57 \pm 13.47 *$ \\
\hline C-reactive protein, mg/l & $\mathrm{M} \pm \mathrm{m}$ & $11.35 \pm 0.71$ & $19.58 \pm 1.62 *$ \\
\hline Erythrocyte sedimentation rate (ESR), $\mathrm{mm} / \mathrm{h}$ & $\mathrm{M} \pm \mathrm{m}$ & $19.35 \pm 0.90$ & $29.12 \pm 1.04$ * \\
\hline
\end{tabular}

Note: * - statistically significant differences in the parameters between the groups of patients without and with NAFLD ( $p<0.05)$.

polyarthritis - in $46.2 \%$. In the patients with concomitant NAFLD, oligo- and polyarthritis were observed in the vast majority (96.5) and monoarthritis in only $3.5 \%$ of those surveyed. The average number of the affected joints in the group was (5.36 \pm 0.38$)$.

The patients in group 2 were characterized by an increase in the number of patients with severe disease course $-18(31 \%)$ and a decrease in the percentage with mild course -7 patients $(12 \%)$ and the average - $33(57 \%)$. At the same time, in group 1 , a severe course was diagnosed in $7(11 \%)$, medium - in $41(63 \%)$, mild - in 17 (26\%) patients.

The intensity of pain according to VAS in the patients of group 2 was in 1.2 times higher than in group $1(p<0.05)$.

The GAS scale was used to evaluate gout activity. It was found that the majority of patients had a high disease activity and, on average, in the patients with concomitant NASH it was in 1.3 times higher than in the patients without liver damage. In 36 (55.4\%) patients of group 1 moderate activity (GAS 4.5-7.4) was present, and 29 (44.6\%) had a high (GAS>7.4) disease activity. 45 (77.6\%) patients of group 2 had high disease activity and 13 (22.4\%) had moderate activity $(p<0.05)$.

In the control group, the level of UA in the serum was $(309.13 \pm 14.16) \mu \mathrm{moL} / \mathrm{L}, \mathrm{CRP}-$ $(3.39 \pm 0.17) \mathrm{mg} / \mathrm{l}, \mathrm{ESR}-(6.47 \pm 0.65) \mathrm{mm} / \mathrm{h}$.

The analysis of laboratory parameters revealed that the examined group 2 experienced an increase in the level of UA in the blood in 1.4 times compare to the patients in group 1 , respectively, up to $(621.57 \pm 13.47)$ and $(459.72 \pm 11.44) \mu \mathrm{moL} / \mathrm{L}(p<0.05)$. The inflammatory process, by the CRP level, was more significant in 1.7 times in the patients with concomitant NAFLD than in group 1. An increase in ESR, as a criterion for the activity and severity of the inflammatory process, occurred among all patients, but mostly in the patients with concomitant liver damage $(29.12 \pm 1.04) \mathrm{mm} / \mathrm{h}$, which was 1.5 times higher than the group 1 parameters $(p<0.05)$.

According to the treatment received by the patients, they were divided into subgroups. 
Group 1 - 27 people (subgroup $1 \mathrm{~A}$ ) received treatment in accordance with the order of the Ministry of Health of Ukraine No. 676, dated October 12, 2006: hypopuricemic therapy with allopurinol according to the scheme, antiinflammatory and analgesics (basic therapy); 38 (subgroup 1B) - additionally enterosorbent carboline 1 teaspoon 3 times a day for 10 days 2 hours before or after meals or medication. Among the patients of group $2-27$ (subgroup $2 \mathrm{~A}$ ) received basic therapy, 35 (subgroup $2 \mathrm{~B}$ ), except basic treatment - carboline according to the scheme. The patients of group 2 were also treated according to the Unified Clinical
Protocol of Primary, Secondary (Specialized) Medical Care "Nonalcoholic fatty liver disease" (Order of the Ministry of Health of Ukraine No. 826, dated November 6, 2014).

Pain, as one of the manifestations of articular syndrome, was the main complaint of all patients before treatment (Table 2). Swelling of the affected joint was present in 53 (81.5\%) patients of group 1 and 54 (93.1\%) of group 2, with redness of the skin in $45(69.2 \%)$ and 56 (97\%), respectively, local temperature rise in 50 (77\%) and 54 (93.1\%) individuals, body temperature rise to subfebrile numbers took place in $11(17 \%)$ and $13(22.4 \%)$ of both groups.

Table 2. The frequency of clinical symptoms in the patients with gout

\begin{tabular}{|l|c|c|}
\hline \multirow{2}{*}{\multicolumn{1}{|c|}{ Symptoms }} & \multicolumn{2}{c|}{ Patients with gout } \\
\cline { 2 - 3 } & Group 1, $\mathrm{n}=65$ & Group 2, $\mathrm{n}=58$ \\
\hline Joint pain and change in joint motion & $65(100 \%)$ & $58(100 \%)$ \\
\hline Swelling & $53(81.5 \%)$ & $54(93.1 \%)$ \\
\hline Redness & $45(69.2 \%)$ & $56(97 \%)$ \\
\hline Local temperature rise & $50(77 \%)$ & $54(93.1 \%)$ \\
\hline Body temperature rise & $11(17 \%)$ & $13(22.4 \%)$ \\
\hline
\end{tabular}

Clinical manifestations of the disease and improvement of personal well-being decreased in the dynamics of treatment of the patients of both groups. In the patients of group 1 a significant improvement of the general condition was observed on the $2^{\text {nd }}-3^{\text {rd }}$ day, and in the patients with concomitant liver damage - swelling, redness of the joint and the intensity of pain decreased on the $3^{\text {rd }}-4^{\text {th }}$ day of the disease, according to VAS, the body temperature was normal.

Thus, in the patients of subgroup $1 \mathrm{~A}$ after the treatment, the intensity of pain according to VAS decreased from $(55.19 \pm 1.4) \mathrm{mm}$ to $(18.41 \pm 3.21) \mathrm{mm}(p<0.001)$, and from $(57.16 \pm 1.4) \mathrm{mm}$ to $(11.66 \pm 2.12) \mathrm{mm}-$ in the subgroup 1B $(p<0.001)$.

Before the treatment, the examined of group 2 complained of severe pain in the affected joints that significantly influenced the functional activity of the patients. After baseline treatment, the pain intensity according to VAS in the subgroup $2 \mathrm{~A}$ decreased from $(69.04 \pm 1.67) \mathrm{mm}$ to $(30.48 \pm 4.68) \mathrm{mm}(p<0.001)$, and in the subgroup 2B (in cases of enterosorbent administration) - from $(69.31 \pm 1.34) \mathrm{mm}$ to $(21.20 \pm 2.82) \mathrm{mm}(p<0.001)$.

The dynamics of UA regression in blood serum during the course of treatment in the patients of group 1 was significantly better compare to those of group 2. In cases of the baseline treatment, the level of UA gradually decreased in the subgroup $1 \mathrm{~A}$ from $(444.01 \pm 18.57)$ to $(389.03 \pm 14.55) \mu \mathrm{moL} / \mathrm{L}$, $\mathrm{p}<0.001$, and in the subgroup $1 \mathrm{~B}$ with additional carboline administration - from $(470.87 \pm 14.38)$ to $(353.01 \pm 7.96) \mu \mathrm{moL} / \mathrm{L}, \mathrm{p}<0.001$. Compare to the control group, this parameter was higher in 1.26 and 1.14 times, respectively. In the subgroup 2A, the level of UA decreased from $(657.03 \pm 11.64)$ to $(529.27 \pm 12.32) \mu \mathrm{moL} / \mathrm{L}$, $\mathrm{p}<0.001$, in the subgroup 2B - from $(598.29 \pm 20.14)$ to $(473.95 \pm 7.75) \mu \mathrm{moL} / \mathrm{L}$, $\mathrm{p}<0.001$, however, it was higher than in the control group in 1.71 and 1.53 times.

Regarding the inflammatory process activity (ESR, CRP), there was a decrease in the level of ESR $(p<0.001)$ and CRP $(p<0.001)$ in the dynamics of treatment in both groups. It should be noted that in the patients of subgroup $1 \mathrm{~B}$ after enterosorbent administration the CRP concentration decreased from $(12.06 \pm 1.01)$ to $(3.51 \pm 0.37) \mathrm{mg} / \mathrm{l}(\mathrm{p}<0.001)$, and ESR - from $(18.47 \pm 1.14)$ to $(7.95 \pm 0.59) \mathrm{mm} / \mathrm{h}(p<0.001)$, compare to the control group these values became normal $(p>0.05)$. In the patients with concomitant NAFLD, in cases of the basic treatment in combination with enterosorbent there was a decrease of CRP - from (19.94 \pm 1.92$)$ to $(7.79 \pm 0.36) \mathrm{mg} / \mathrm{l}(p<0.001), E S R-$ from $(30.51 \pm 1.37)$ to $(11.94 \pm 0.42) \mathrm{mm} / \mathrm{h}(p<0.001)$, but they were in 2.3 and 1.8 times higher than in the almost healthy individuals $(p<0.001)$. 


\section{Discussion}

Comorbidity is still an important problem in medicine, since studying the manifestations of the combined pathology of different body systems can help uncover the mechanisms of disease formation and development of pathogenetically profound therapy [12].

At present gout is an urgent problem because its prevalence has doubled in the last decades. This disease becomes even more significant due to its comorbidity. Frequent combination of gout with concomitant pathology leads to a decrease in the effectiveness of treatment and progression of complications [13].

Currently, there is a high morbidity of NAFLD in the world, and there is a tendency to increasing incidence of this chronic liver disease in the population, development of severe complications in the disease progression that is an urgent issue of contemporary medicine. The presence of NAFLD, as a comorbid condition, enhances the inflammatory response in the body and significantly complicates the course of the underlying disease [14].

It is indisputable fact that the main link of gout pathogenesis is UA metabolism. The determination of the dynamics of UA levels in the blood in gout and concomitant NAFLD is increasingly significant as a risk factor for cardiovascular events [15].

In most such patients, prior to treatment, an increase in CRP and ESR is proved. It is established that in this pathology an inflammatory process develops, which is not only limited to local changes in the joints, but also causes a response of the whole body. The increase in CRP in the patients with gout in combination with NAFLD confirms the presence of chronic subclinical inflammation in them, and with the progression of the disease there is an increase in the level of CRP [16].

Treatment of the patients with gout should be aimed at eliminating the acute attack of arthritis and inflammatory changes in the joints, reducing the content of UA compounds in the body, eliminating extra-articular lesions associated with gout, restoring the function of the musculoskeletal system, etc. [17].

It should be noted that the use of enterosorption together with basic therapy has a positive effect on the clinical course of the disease, promotes faster regression of intoxication, pain and articular syndromes, as well as is accompanied by a decrease of inflammatory process activity in the body (CRP, ESR) and uric acid level in blood serum.

\section{Conclusions}

The course of gout in the patients with concomitant nonalcoholic fatty liver disease is more severe than in its absence. With this combination, the number of the affected joints, tophi, acute conditions increases for the period of a year. There is an increase of the intensity of pain according to visual analogue scale, as well as its activity by the Gout activity score. The inflammatory process intensifies. The inclusion of carbon granulated enterosorbent carboline in the complex treatment of the patients with gout or without concomitant nonalcoholic fatty liver disease, contributes to a faster reverse dynamic of clinical manifestations of the disease, accompanied by a more significant decrease in C-reactive protein, erythrocyte sedimentation rate and uric acid in blood serum.

\section{Funding}

This research received no external funding. Conflict of Interests

The author declares no conflict of interest.

\title{
ПОДАГРА І НЕАЛКОГОЛЬНА ЖИРОВА ХВОРОБА ПЕЧІНКИ: ЕФЕКТ ДОДАТКОВОГО ЗАСТОСУВАННЯ ЕНТЕРОСОРБЦЇ̈ В ЗАГАЛЬНОМУ ЛІКУВАННІ
}

\author{
У.О. Мудра \\ ТЕРНОПІЛЬСЬКИЙ НАЦІОНАЛЬНИЙ МЕДИЧНИЙ УНІВЕРСИТЕТ ІМЕНІ І.Я. ГОРБАЧЕВСЬКОГО, \\ ТЕРНОПІЛЬ, УКРАЇНА
}


та неалкогольного стеатогепатиту. Комплексне патогентичне лікування хворих, спрямоване на різні ланки патологічного процесу, останнім часом доповнене застосуванням ентеросорбентів.

Мета дослідження. Вивчити клінічні особливості перебігу подагри при супутньому неалкогольному стеатогепатиті (НАСГ) й оцінити вплив вуглецевого ентеросорбенту на ії перебіг.

Методи дослідження. Обстежено 123 хворих на подагру, які перебували на стаціонарному лікуванні. Їх було поділено на 2 групи. До 1-ї групи ввійшли пацієнти з подагрою без ураження печінки, до 2-ї- хворі із супутнім НАСГ. Кожну із цих груп було розділено на підгрупи, пацієнти однієї з яких, окрім базоваго лікування, отримували вуглецевий ентеросорбент карболайн. Контрольну групу склали 30 практично здорових осіб. В клінічному обстеженні хворих враховували скарги, дані анамнезу, проводили фізикальний огляд, визначали вміст сечової кислоти (СК), С-реактивного білка (СРБ), швидкості осідання еритроцитів (ШОЕ) в сироватці крові. Активність подагри оцінювали за допомогою шкали Gout Activity Score (GAS).

Результати. Застосування базового лікування в поєднанні з вуглецевим ентеросорбентом сприяло швидшій регресії інтоксикаційного, больового й суглобового синдромів, а також показників активності запального процесу.

Висновки. Перебіг подагри у хворих з супутнім НАСГ тяжчий, ніж за його відсутності. Включення вуглецевого гранульованого ентеросорбенту карболайн в комплексне лікування хворих на подагру 3 супутнім НАСГ чи без нього у фазі загострення, сприяє швидшій зворотній динаміці клінічних $i$ лабораторних проявів захворювання, супроводжується більш значним зниженням рівня СРБ, ШОЕ та СК у сироватці крові.

КЛЮЧОВІ СЛОВА: подагра; неалкогольний стеатогепатит; ентеросорбент; лікування.

Відомості про автора

Мудра Уляна Олегівна - аспірант кафедри пропедевтики внутрішньої медицини та фтизіатрії Тернопільського національного медичного університету імені І.Я. Горбачевського.

\section{Information about the author}

Uliana O. Mudra - Ph.D. student, Department of Internal Medicine Propedeutics and Phthisiology of I. Horbachevsky Ternopil National Medical University, Ternopil, Ukraine.

ORCID 0000-0001-8160-4962, e-mail: heliosmuo@gmail.com

\section{References}

1. Herasymenko SI, Poluliakh MV, Duda MS, Pshenychnyi TIe. Current aspects of conservative treatment of acute gouty arthritis. Chronicle of traumatology and orthopedics. 2013;1-2:204-7.

2. Orlova IV. Influence of disease activity on quality of life of patients with gout. Ukrainian Journal of Medicine, Biology and Sport. 2018;3(5):127-31.

doi: 10.26693/jmbs03.05.127

3. Aung T, Myung G, FitzGerald JD. Treatment approaches and adherence to urate-lowering therapy for patients with gout. Patient Prefer Adherence. 2017;11:795-800.

doi:10.2147/PPA.S97927

4. Edwards NL, Sundy JS, Forsythe A, Blume S, Pan F, Becker MA. Work productivity loss due to flares in patients with chronic gout refractory to conventional therapy. J Med Econ. 2011;14(1):10-5.

doi: $10.3111 / 13696998.2010 .540874$

5. Svintsitskyi AS. Current views on the diagnosis and treatment of gout. Health of Ukraine. Rheumatolog. 2013 February: 70-2.

6. Barskova VG, Eliseev MS, Denisov IS, Eliseeva $M E$, Belikov OA, Fadienko GR, i dr. The frequency of metabolic syndrome and concomitant diseases in patients with gout. Data from a multicenter study. Scientific and Practical Rheumatology. 2012;6(50):15-8.
7. Bardin T, Richette P. Impact of comorbidities on gout and hyperuricaemia: an update on prevalence and treatment options. BMC Med. 2017; 15(1): 123.

doi:10.1186/s12916-017-0890-9

8. Skliarov YeYa., Aksentiichuk KhB., Kurliak NV. Monitoring of liver function disorders in patients with non-alcoholic fatty liver disease on the background of metabolic syndrome. Hepatology. 2015;1: 34-41.

9. Tkachuk SO, Bashta HV, Lapovets LIe, Zaletskyi MP. Changes in carbohydrate and lipid metabolism and C-reactive protein in patients with coronary heart disease and fatty hepatosis. Medical and Clinical Chemistry. 2016;18(4):29-33.

doi: 10.11603/mcch.2410-681X.2016.v0.i4.7252

10. Kondratiuk VIe, Tarasenko OM. Hyperuricemia and gout: the current state of the problem. Ukrainian Rheumatology Journal. 2016;3:30-7.

11. Scirè C, Carrara G, Viroli C, Cimmino M, Taylor W, Manara M, et al. Development and First Validation of a Disease Activity Score for Gout. Arthritis Care \& Research. 2016; 68 (10): 1530-7.

doi: 10.1002/acr.22844

12. Abrahamovych OO, Faiura OP, Abrahamovych UO. Comorbidity: a modern perspective on the 
problem; classification (message second). Lviv Clinical Bulletin. 2016;1:31-9.

13. Svintsitskyy AS, Kozak NP, Ostafiichuk AS. Pecularities of gouts' course in association with the metabolic syndrome. Ukrainian Rheumatology Journal. 2011;4:46.

14. Younossi ZM. Non-alcoholic fatty liver disease - a global public health perspective. J. Hepatol. 2019;70(3):531-44.

doi: $10.1016 /$ j.jhep.2018.10.033
15. Pillinger MH, Goldfarb DS, Keenan RT. Gout and its comorbidities. Bull NYU Hosp Jt Dis. 2010;68(3):199-203.

16. Orlovsky VF, Murenets NO. Chronic inflammation in nonalcoholic fatty liver disease. Pathologia. 2010;7(3):99-102.

17. Svintsitskiy AS. Diagnosis and treatment of rheumatic diseases: manual. Kiev: The Publishing House of the Medknyga; 2017. 372 p.

Received 06 September 2019; revised 11 October 2019; accepted 21 October 2019.

This is open access article distributed under the Creative Commons Attribution License, which permits unrestricted use, distribution, and reproduction in any medium, provided the original work is properly cited. 